Accepted

23. 07. 2020

Revised

07. 10. 2020

Published

29. 10. 2020

Keywords

basic

life

support,

advanced

life

support,

workloads,

resuscitation

team,

feelings,

healthcare

workers.

\section{EXPERIENCING STRESS AMONG NURSES During Resuscitation Procedure and LEGAL OBLIGATIONS FOR HEALTHCARE WORKERS IN SLOVENIA}

\author{
Anton Koželj ${ }^{1}$, Maja Strauss ${ }^{1} \&$ MATEj StrnaD ${ }^{2}$ \\ ${ }^{1}$ University of Maribor, Faculty of Health Sciences, Maribor, Slovenia. \\ E-mail: anton.kozelj@um.si,maja.strauss@um.si \\ ${ }^{2}$ University of Maribor, Faculty of Medicine, Maribor, Slovenia. \\ E-mail: strnad.matej78@gmail.com \\ CORRESPONDING AUTHOR \\ anton.kozelj@um.si
}

\begin{abstract}
Nurses are always part of the team that performs resuscitation procedures. In this paper the authors explore the influence that resuscitation procedures on nurses who perform them. For data collection, the authors used a survey with a convenience sample of nurses who work in emergency settings. For statistical processing of data, the authors used the calculation of frequency, standard deviation, means, and median. Authors used Spearman's rank correlation coefficient and calculated the $\mathrm{p}$-value. The respondents in the survey completed the Post-Code Stress Scale. The results show that the majority of the respondents experienced resuscitation cases as burdensome situations; however, the level of stress was moderate. Nurses still experience some physical and psychological symptoms during resuscitations.
\end{abstract}




\section{$1 \quad$ Introduction}

Cardiac arrests requiring hospitalization, and resuscitative procedures, constitute extreme medical emergencies. These procedures are essential interventions used to restore cardiopulmonary function and prolong life (Panesar, et al., 2014). Participation of a critical care nurse in an unsuccessful resuscitation can create a unique heightened level of psychological stress referred to as postcode stress, and which can lead to activation of coping behaviors, and symptoms of posttraumatic stress disorder (PTSD) (McMeekin, 2017).

Cardiopulmonary resuscitation (CPR) has been used in hospitals for approximately 50 years. Nurses are generally the first responders to a cardiac arrest and initiate basic life support while waiting for the advanced cardiac life support team to arrive. Speed and competence on the part of the first responders are critical factors contributing to the initial survival of a person following a cardiac arrest (Dwyer \& Williams, 2002). Since its introduction in the 1960s, CPR has saved untold number of lives and ensured years of productive life for survivors (Ryan, 1998; Ballew, 1997). A significant factor in the success rate is the skill level of nurses and doctors in basic life support (BLS) procedures (Inwood, 1996). Several studies on the resuscitation skills of health professionals show many are ineffective in resuscitation (McGowan, et al., 1999; Inwood, 1996).

Each year, thousands of critical care nurses in the United States and worldwide perform CPR (Hinderer, et al., 2012; Chang, et al., 2009; Enohumah, et al., 2006; Myrianthefs, 2003). It is estimated that between 40 and 84 percent of all resuscitation attempts performed within critical care units result in the immediate or imminent death of the patient within 24 hours (Hinderer, et al., 2012; Gershengorn, 2012; Enohumah, et al., 2006; Pembeci, 2006). Because critical care nurses have frequent and cumulative exposures to unsuccessful CPR's, psychological trauma often ensues (Mealer, 2007). Despite a growing workforce demand for registered nurses in critical care, turnover, and vacancy rates are high (Fitzpatrick, 2010). Critical care nurses, as an inherent aspect of their work, participate in life-sustaining procedures, one of them being CPR. These experiences in turn can diminish their ability to effectively manage and cope with negative emotions and can also trigger a significant decrease in their psychological health. Repeated participation in unsuccessful resuscitation attempts creates a unique form of psychological stress, known as postcode stress, 
which has significant effects on the psychological health of registered nurses across practice settings. Postcode stress is posited to initiate processes for regulating emotions, such as coping behaviors, that aim to maintain an individual's psychological health and prevent the manifestation of stress-associated symptoms (Cole, Slocumb, Muldon Mastey, 2001; Laws, 2001). The differences in coping behaviors used may offer insights into to why individuals have different psychological outcomes (PTSD symptom severity) after similar events (Desbiens \& Fillion, 2007). Distinct from moral distress, which occurs when critical care nurses are unable to act on moral decisions or judgments in practice, postcode stress is the acute psychological response to unsuccessful resuscitation participation with specific emotional and physical stressors or antecedents (Fitzpatrick, 2010; Zuzelo, 2007). Physical signs and sounds during resuscitation, such as color changes, gasping, emesis, and indignities suffered by patients are perceived as stressful by nurses (Issak \& Paterson, 1996).

The aim of the study was to explore experiences among the nurses before, during, and after being involved in the resuscitation procedures. Specifically, our goal was to determine the occurrence of certain physical and mental signs that can be detected in participants during resuscitation. Such situations are very stressful. Additional disruptive factors can further increase the level of stress. This can also lead to poorer functioning and reactions of nurses in resuscitation procedures, and can also affect the adverse outcome of resuscitation. We wanted to explore how disturbing twenty specific situations are for nurses, and to expose those that are so disruptive that they can potentially even affect the outcome of resuscitations.

\section{Legal obligations in Slovenia that cover the field of resuscitation}

Healthcare professionals have numerous responsibilities. The broadest type is a moral responsibility. The next type is an occupational-deontological responsibility, which is one that relates to the rules of the profession covered by the professional deontological code. This type of responsibility establishes high standards for the fulfillment of professional duties and codifies sanctions for breaches of those duties. Lastly, there are different types of legal liability, which - in this hierarchy - include 
disciplinary liability, liability for damage, and criminal liability for the crime committed (Korošec, 2004)1.

'First aid is direct medical care received by the injured or suddenly ill at the scene and as soon as possible after the event, which is carried out with simple aids and improvisation, including improvised transport, which lasts until professional help arrives or until adequate professional assistance is obtained for the patient.' (Balažic, 2006: 3-4). The lay population has an obligation to provide first aid as well. Until professional help arrives, they should do the best they can according to their knowledge. Basic life support most certainly belongs to this category.

Providing medical treatment, on the other hand, falls exclusively under the province of the doctor. During first aid procedures, we deviate from this principle and justify the deviation on the grounds that the doctor entrusts a certain proportion of the right of treatment to a non-doctor in this area because of its extreme urgency (Zakon o zdravniški služba - Medical Practitioners Act (ZZdrS)).

In 1965, the Slovene legislation explicitly noted for the first time that every citizen has the legal duty to provide first aid. This legislation has endured to the present time in the Republic of Slovenia. The legal regulation has established the leading thought that in new relationships between people, the emergency medical condition of one of them cannot and should not remain their private matter only, but it necessarily concerns everyone aware of them and who can help. The regulation states as follows:

"Everyone is obliged to belp the injured or the ill in an emergency, to do the best of their ability, to provide first aid and enable them access to emergency medical care (Balažic, 2006)."

The duty to provide first aid is twofold:

- general duty of every citizen,

- a duty to provide first aid to any healthcare professional identified as "emergency medical assistance" (Balažic, 2006).

\footnotetext{
${ }^{1}$ All translations from Slovene sources in this article are own translations.
} 
Emergency medical care includes emergency services whose failure would, in the short term, lead to irreparable and severe deterioration of health or death. The doctor is obligated to provide such assistance in accordance with not only the code of medical deontology but also with the medical state-of-the-art (Art. 43(1) ZZdrS).

Previous versions of the Code of Medical Deontology (Kodeks medicinske deontologije Slovenije - Art. 6) stipulated that doctors could not refuse to administer emergency medical assistance that was within their professional competence, irrespective of whether they were on duty, and irrespective of whether they were explicitly asked for assistance. Article 2 of the extant Code of Medical Ethics (Kodeks zdravniške etike) stipulates that in the case of medical emergencies the doctor must offer assistance to everyone.

A doctor or other healthcare professional who, contrary to his or her professional duty, fails to assist the patient or any other person at risk of life, shall be punished by imprisonment for a term not exceeding one year (Art. 178 Kazenski zakonik Criminal Code (KZ-1). A doctor who acts negligently and contrary to the rules of the medical science and profession in the performance of the medical activity and thus causes a serious impairment of the health of the patient, shall be punished by imprisonment for a term not exceeding three years. Any other healthcare professional who acts negligently and contrary to the rules of the medical profession in the performance of medical activity and thus causes a significant deterioration of the patient's health should be punished in the same way. If the act of negligence causes someone to die, the person shall be punished by imprisonment for a term between one and eight years (Art. $179 \mathrm{KZ}-1$ ).

The responsibility for refusing to provide first aid and emergency medical care is bound by legal and ethical criteria: The greater the need for assistance, the more severe the penalty will be imposed on the person who did not provide it. The most severe are the cases involving fatalities. The second criterion is the professional competence of the person who failed to provide assistance in emergency medical care. The doctor bears the largest obligation. 
If the patient is incapable of making a decision or unable to express their will, the emergency aid can be performed without his or her consent (Art. 28 Zakon o pacientovih pravicah - Patients' Rights Act (ZPacP); Kraljić, 2010). Emergency aid can also be performed on a child when it is rejected by the parent or guardian (Art. $36 \mathrm{ZPacP})$.

The following articles of the Slovenian Code of Ethics for Nurses (Kodeks etike v zdravstveni negi in oskrbi Slovenije) apply to the topic at hand:

Principle 1: "Nurses and healthcare providers are committed to maintaining people's lives and health. They are further obliged to perform their work in a bumane, professional, quality, safe, compassionate, responsible, conscientious manner, and with respect to the needs, values, and beliefs of the patient."

Principle 2: "Nursing and healthcare providers respect the patients' right to choose and make decisions."

Principle 3: "Nurses and healthcare providers respect the dignity and privacy of the patients in all conditions of health, illness, dying, and after death."

Principle 4: "Nurses and healthcare providers provide patients with competent nursing care within their areas of responsibility. Two standards of operation within the principle four are: nurses must not refuse emergency medical assistance within their professional competence, whether or not they have been explicitly asked for such assistance, and they must respond to work in exceptional circumstances, aware of their moral and legal responsibilities."

Principle 5: "The decisions and work of nursing and healthcare providers must be such to benefit the patient."

Slovenia not only has some laws but also a Code of Ethics that pertains to the obligations of the health workers during resuscitation procedures. On the one hand, these laws delineate nurses' specific obligations and provide certainty regarding actions nurses must take under specific circumstances. On the other hand, additional obligations can present additional burdens, because nurses must act not only 
according to the mentioned obligations but also in responsible ways that are not necessarily specified in legislative acts.

By way of example, there are several scenarios that are still undefined in the legislation, and accordingly fall into what me might term the "grey area", such as:

- whether or not to resuscitate a patient who had previously refused resuscitation in a written request;

- whether or not a doctor's phone order is acceptable to any individual nurse;

- whether or not to start or abandon resuscitation in special circumstances, or special clinical situations;

- whether or not to resuscitate a patient because of specific circumstances surrounding the illness (e.g., terminal cancer patient, etc.);

- whether or not to respect the demands and expectations of relatives (parents, next of kin) when they differ from our (professional) opinion.

In cases where doctors are not present, nurses in Slovenia are limited in actions they may take during resuscitation. Kešpet (2013) states that more than half of the respondents in his research in Slovenia have limited knowledge about the laws that cover the topics concerned. More than half of them (60 percent) would not resuscitate a patient who had previously declared that they did not want to be resuscitated. Furthermore, the views regarding phone orders are different statistically among doctors and nurses. Within the group of nurse respondents, 55 percent of them would refuse to administer emergency drugs upon merely the doctor's telephone order.

\section{Methods}

Our study utilized cross-sectional observational research. For the data collection, the authors employed a survey method and a convenience sample of registered nurses who work in emergency units (hospital and prehospital). Medical technicians and doctors were not included in the research. We used the Post-Code Stress Scale (Cole, Slocumb \& Muldon Mastey, 2001) to measure the magnitude of the psychological stress associated with CPR perceived by nurses who perform CPR because this scale was specially designed for measuring stress among the population of nurses during 
resuscitation cases. Participants chose one item on a 5-point Likert scale (1 - does not bother me at all; 2 - it bothers me somewhat; 3 - I am undecided or do not know if it bothers me; 4 - it bothers me moderately; 5 - it bothers me a lot). The survey was carried out from March until May 2019 at the University Medical Centre Maribor. The questionnaires were distributed directly among the nurses or given to the department heads, and additional explanations were provided if necessary. Based on the literature review, it was decided that the last two estimates would be considered as burdensome (most disturbing) answers (4 and 5). Prior reliability testing with a sample of critical care nurses demonstrated good internal consistency, Cronbach's $\alpha=0.79$ (Cole, Slocumb, Muldon Mastey, 2001); in one of their studies, only 14 items were used, and the internal consistency was Cronbach's $\alpha=0.84$ (McMeekin, et al., 2017). The internal consistency reliability for the Post-Code Stress Scale in our research was Cronbach's $\alpha=0.83$. For statistical processing of data, we used the calculation of frequency, standard deviation, means, median, and Spearman correlation test. A " $\mathrm{p}$ " value of less than 0,05 and correlation strength values of more than 0,30 were accepted as statistically significant (Hinkle, et al., 2003, Mukaka, 2012). Statistical software IBM SPSS Statistics V22 were used for this pilot study, where we wanted to test the feasibility, accessibility, and willingness of the selected population to participate in the research and costs of the research. According to statistical data from the Slovenian National Institute of Public Health, there are 7.152 registered nurses in Slovenia (NIJZ, 2019). For the final study, the plan is to survey 365 respondents (95 percent confidence level) (Raosoft, 2004). For the pilot study, 12 percent of the calculated population was used. 50 questionnaires were distributed and 44 returned. Ethical approval was obtained through the National Medical Ethics Committee of Slovenia by the Ministry of Health (reference number: 0120-517/2017/5). The respondents filled out questionnaires voluntarily and signed a consent document before completing the questionnaires.

\section{$3 \quad$ Results}

The questionnaires returned were equally represented by gender and among nurses who work in a hospital and prehospital area (Table 1). Since we do not have a paramedic system per se in Slovenia, nurses work in ambulance vehicles, together with the driver/medical technician or, in some cases, doctors too. The age of the majority of the respondents' ranged from between 31- 40 years. Other sample characteristics are presented in Table 1. 
Table 1: Sample characteristics $(n=44)$

\begin{tabular}{|c|c|c|}
\hline Variable & $\begin{array}{l}\text { Frequency } \\
\text { (n) }\end{array}$ & $\begin{array}{l}\text { Valid } \\
(\%)\end{array}$ \\
\hline \multicolumn{3}{|l|}{ Gender } \\
\hline Male & 22 & 50 \\
\hline Female & 22 & 50 \\
\hline Total & 44 & 100 \\
\hline \multicolumn{3}{|l|}{ Age (Years) } \\
\hline $20-30$ & 12 & 27,26 \\
\hline $31-40$ & 16 & 36,36 \\
\hline $41-50$ & 8 & 18,19 \\
\hline $51-60$ & 7 & 15,91 \\
\hline$>60$ & 1 & 2,28 \\
\hline Total & 44 & 100 \\
\hline Emergency care & $\begin{array}{l}\text { Frequency } \\
\text { (n) }\end{array}$ & $\begin{array}{l}\text { Valid } \\
(\%)\end{array}$ \\
\hline Hospital & 22 & 50 \\
\hline Prehospital & 22 & 50 \\
\hline Total & 44 & 100 \\
\hline \multicolumn{3}{|c|}{ Number of years working in the emergency care } \\
\hline $2-5$ years & 17 & 38,6 \\
\hline $6-10$ years & 7 & 15,9 \\
\hline $11-20$ years & 12 & 27,3 \\
\hline $21-30$ years & 4 & 9,1 \\
\hline$>30$ years & 4 & 9,1 \\
\hline Total & 44 & 100,0 \\
\hline \multicolumn{3}{|c|}{$\begin{array}{l}\text { The approximate number of reanimations per year } \\
\text { without a doctor present }\end{array}$} \\
\hline$<10$ resuscitations per year & 36 & 81,8 \\
\hline 10 do 20 resuscitations per year & 5 & 11,4 \\
\hline 21 - 30 resuscitations per year & 0 & 0 \\
\hline$>40$ resuscitations per year & 3 & 6,8 \\
\hline Total & 44 & 100,0 \\
\hline \multicolumn{3}{|c|}{$\begin{array}{l}\text { The approximate number of reanimations per year with } \\
\text { a doctor leading the team }\end{array}$} \\
\hline$<10$ resuscitations per year & 20 & 45,5 \\
\hline 10 do 20 resuscitations per year & 18 & 40,9 \\
\hline 21 - 30 resuscitations per year & 3 & 6,8 \\
\hline$>40$ resuscitations per year & 3 & 6,8 \\
\hline Total & 44 & 100,0 \\
\hline
\end{tabular}


Table 2: Results based on the 20 claims from the Post-Code Stress Scale

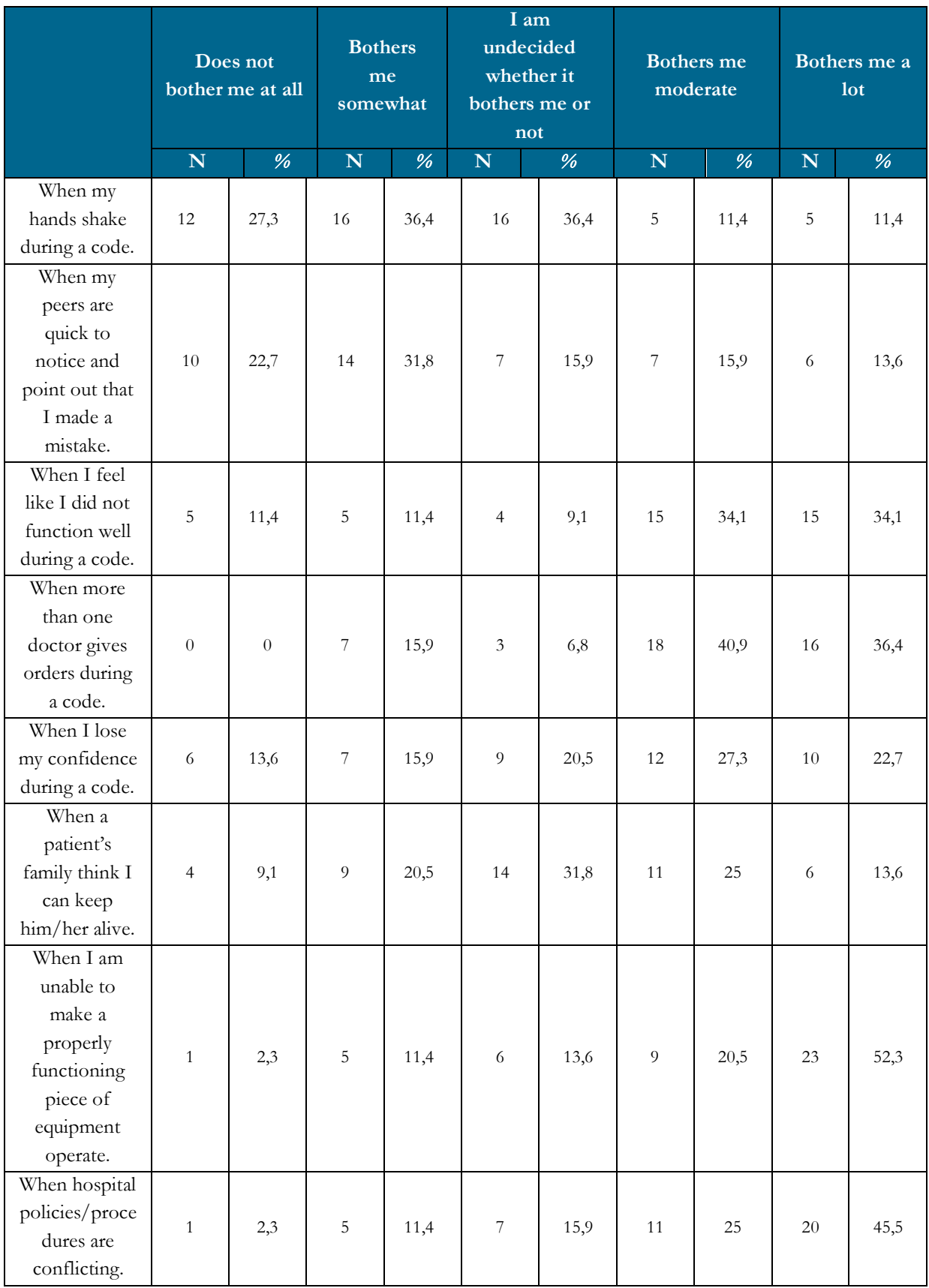




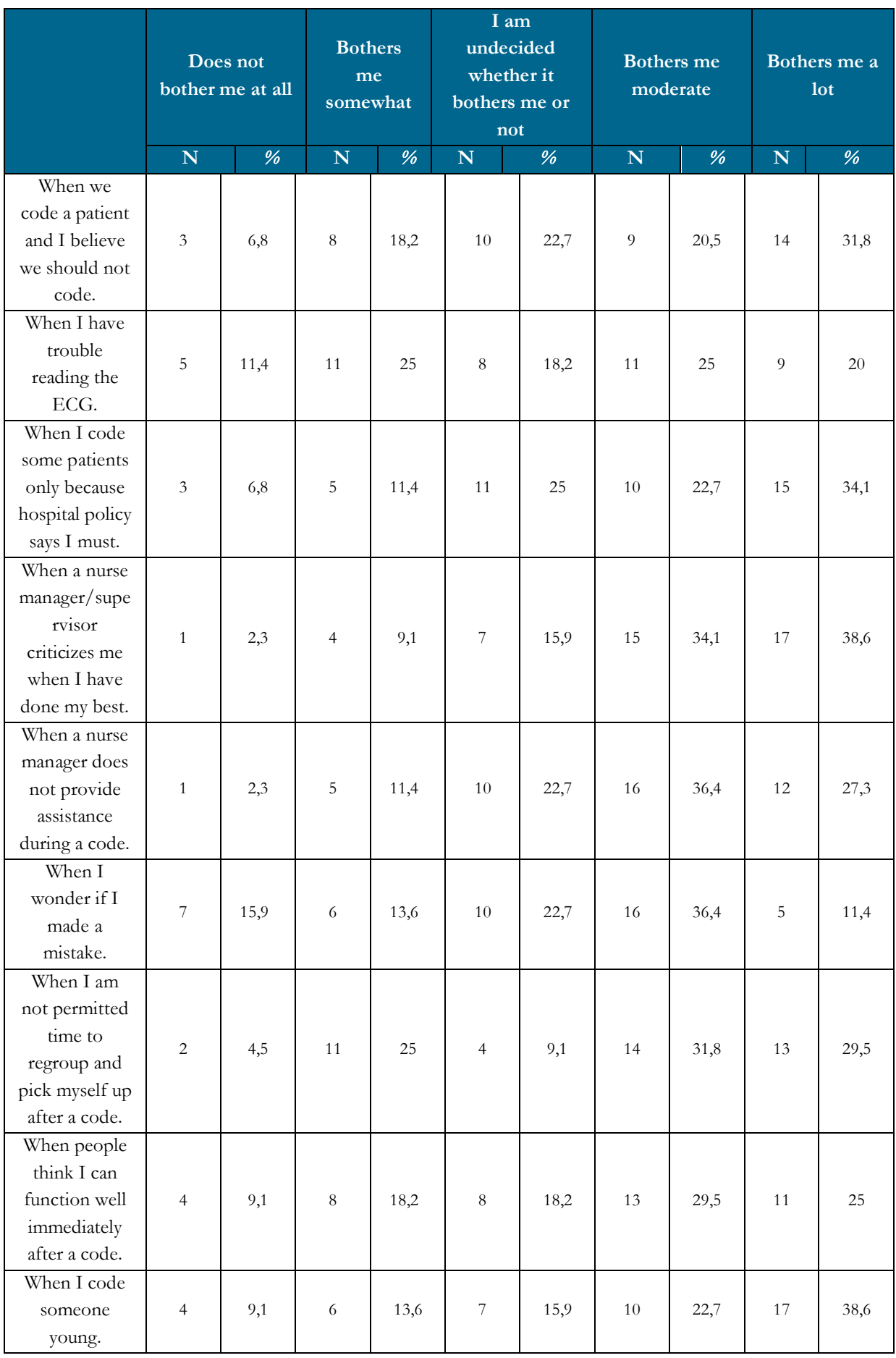




\begin{tabular}{|c|c|c|c|c|c|c|c|c|c|c|}
\hline & \multicolumn{2}{|c|}{$\begin{array}{c}\text { Does not } \\
\text { bother me at all }\end{array}$} & \multicolumn{2}{|c|}{$\begin{array}{l}\text { Bothers } \\
\text { me } \\
\text { somewhat }\end{array}$} & \multicolumn{2}{|c|}{$\begin{array}{c}\text { I am } \\
\text { undecided } \\
\text { whether it } \\
\text { bothers me or } \\
\text { not }\end{array}$} & \multicolumn{2}{|c|}{$\begin{array}{l}\text { Bothers me } \\
\text { moderate }\end{array}$} & \multicolumn{2}{|c|}{$\begin{array}{c}\text { Bothers me a } \\
\text { lot }\end{array}$} \\
\hline & $\mathbf{N}$ & $\%$ & $\mathbf{N}$ & $\%$ & $\mathbf{N}$ & $\%$ & $\overline{\mathbf{N}}$ & $\%$ & $\mathbf{N}$ & $\%$ \\
\hline $\begin{array}{l}\text { When no one } \\
\text { talks about the } \\
\text { code after it is } \\
\text { over. }\end{array}$ & 6 & 13,6 & 5 & 11,4 & 15 & 34,1 & 10 & 22,7 & 8 & 18,2 \\
\hline $\begin{array}{l}\text { When I think } \\
\text { I might have } \\
\text { missed a sign } \\
\text { that would } \\
\text { predict the } \\
\text { code. }\end{array}$ & 2 & 4,5 & 6 & 13,6 & 9 & 20,5 & 12 & 27,3 & 15 & 34,1 \\
\hline $\begin{array}{l}\text { When the } \\
\text { patient dies. }\end{array}$ & 5 & 11,4 & 6 & 13,6 & 20 & 45,5 & 11 & 25 & 2 & 4,5 \\
\hline TOTAL: & 82 & & 149 & & 185 & & 235 & & 239 & \\
\hline
\end{tabular}


Table 3: Average values of the answers:

\begin{tabular}{|c|c|c|c|}
\hline & $\begin{array}{c}\text { Mean* } \\
(1-5)\end{array}$ & $\begin{array}{l}\text { Standard } \\
\text { Deviation }\end{array}$ & Median \\
\hline When my hands shake during a code. & 2,43 & 1,32 & 2,00 \\
\hline $\begin{array}{l}\text { When my peers are quick to notice and point out that I } \\
\text { made a mistake. }\end{array}$ & 2,66 & 1,36 & 2,00 \\
\hline When I feel like I did not function well during a code. & 3,68 & 1,36 & 4,00 \\
\hline When more than one doctor gives orders during a code. & 3,98 & 1,05 & 4,00 \\
\hline When I lose my confidence during a code. & 3,30 & 1,36 & 3,50 \\
\hline When a patient's family think I can keep him/her alive. & 3,14 & 1,17 & 3,00 \\
\hline $\begin{array}{l}\text { When I am unable to make a properly functioning piece } \\
\text { of equipment operate during a code. }\end{array}$ & 4,09 & 1,16 & 5,00 \\
\hline When hospital policies/procedures are conflicting. & 4,00 & 1,14 & 4,00 \\
\hline $\begin{array}{l}\text { When we code a patient and I believe we should not } \\
\text { code. }\end{array}$ & 3,52 & 1,30 & 4,00 \\
\hline When I have trouble reading the ECG. & 3,18 & 1,33 & 3,00 \\
\hline $\begin{array}{l}\text { When I code some patients only because hospital policy } \\
\text { says I must. }\end{array}$ & 3,66 & 1,26 & 4,00 \\
\hline $\begin{array}{l}\text { When a nurse manager/supervisor criticizes me when I } \\
\text { have done my best. }\end{array}$ & 3,98 & 1,07 & 4,00 \\
\hline $\begin{array}{l}\text { When a nurse manager does not provide assistance } \\
\text { during a code. }\end{array}$ & 3,75 & 1,06 & 4,00 \\
\hline When I wonder if I made a mistake. & 3,14 & 1,27 & 3,00 \\
\hline $\begin{array}{l}\text { When I am not permitted time to regroup and pick } \\
\text { myself up after a code. }\end{array}$ & 3,57 & 1,28 & 4,00 \\
\hline $\begin{array}{l}\text { When people think I can function well immediately } \\
\text { after a code. }\end{array}$ & 3,43 & 1,30 & 4,00 \\
\hline When I code someone young. & 3,68 & 1,36 & 4,00 \\
\hline When no one talks about the code after it is over. & 3,20 & 1,27 & 3,00 \\
\hline $\begin{array}{l}\text { When I think I might have missed a sign or symptom } \\
\text { that would have helped me predict that the patient } \\
\text { would code. }\end{array}$ & 3,73 & 1,21 & 4,00 \\
\hline When the patient dies. & 2,98 & 1,02 & 3,00 \\
\hline
\end{tabular}

*The mean values were calculated based on the average estimate of each disturbing factor on a scale from 1 to 5 . Mark. 1 means that the situation is undisturbed for the respondent, and mark. 5 means that the situation is very disturbing for the respondent.

As can be seen from the table above, the respondents had the least problem (bothered them least), with the following claims:

- When my hands shake during a code (mean value 2,43).

- When my peers are quick to notice and point out that I made a mistake (mean value 2,66). 
- When the patient dies (mean value 2,98) (Table 3).

The most burdensome (most disturbing) four claims were:

- when I am unable to make a properly functioning piece of equipment operate during a code (mean value 4,09);

- when hospital policies/procedures are conflicting (mean value 4,00);

- when a nurse manager/supervisor criticizes me when I have done my best: (mean value 3,98 ); and

- when more than one doctor gives orders during a code: (mean value 3,98). (Table 3).

\subsection{Correlations between demographics and claims}

Low positive correlation was observed between "Years of work in healthcare" and "When I feel like I did not function well during a code". The correlation coefficient was $0,320, p=0,03$. The more years the nurses worked in health care, the more they were disturbed by the feeling that they did not function well during a code.

Similarly, low positive correlation was observed between "Years of work in healthcare" and "When hospital policies/procedures are conflicting". The correlation coefficient was $0,326, p=0,016$. Again, the longer the nurses worked in health care, the more they were disturbed by the conflicts with hospital policies/procedures.

Statistically more important correlations were found between "Age" and "When I code some patients only because hospital policy says I must". The correlation coefficient was $0,410, p=0,006$, and in the case of "Years of work in healthcare" and "When I code some patients only because hospital policy says I must", the correlation coefficient was $0,464, p=0,002$. Older nurses with longer work experiences were more disturbed by the demands of the hospital policy that they disagree with. 
Low positive correlation was shown between "Age" and "When I wonder if I made a mistake" (correlation coefficient was $0,331, p=0,028$ ) and in the case of "Years of working in healthcare" and "When I wonder if I made a mistake", the correlation coefficient was $0,303, p=0,046$. The older respondents with longer work experiences were more bothered by the fact that they may have made some mistakes.

The same low positive correlation was shown between "Age" and "When I code someone young", where the correlation coefficient was $0,362, p=0,016$.

The low negative correlation was observed between "Approximate number of reanimations per year without a doctor being present" and "When no one talks about the code after it is over". The correlation coefficient was - 0,316, $\mathrm{p}=0,037$. The more often the nurses have reanimated without a doctor present, the less they discussed that later.

\subsection{Correlations between claims}

For some claims, correlations between them can be observed, for example: "When my hands shake during a code" correlated with "When my peers are quick to notice and point out that I made a mistake" (correlation coefficient was $0,317, \mathrm{p}=0,036$ ), "When I have trouble to reading the ECG" (correlation coefficient was 0,431, p = $0,004)$, and "When a nurse manager does not provide assistance during a code" (correlation coefficient was $0,422, \mathrm{p}=0,004)$.

The claim "When my peers are quick to notice and point out that I made a mistake" correlated with "When I feel like I did not function well during a code", (correlation coefficient was $0,431, \mathrm{p}=0,003)$, "When more than one doctor gives orders during a code", (correlation coefficient was $0,306, p=0,034)$, "When I lose my confidence during a code", (correlation coefficient was $0,538, \mathrm{p}=<0,001$ ), and "When a nurse manager does not assist in a code" (correlation coefficient was $0,387, \mathrm{p}=0,009$ ).

The claim "When I feel like I did not function well during a code" correlated with the claims "When more than one doctor gives orders during a code", (correlation coefficient was $0,476, \mathrm{p}=0,001)$, "When I lose my confidence during a code" (correlation coefficient was $0,519, \mathrm{p}=<0,001$ ), and "When a nurse manager does not provide assistance during a code" (correlation coefficient was $0,361, \mathrm{p}=0,016$ ). 
The claim "When more than one doctor gives orders during a code" correlated with the following claims: "When I feel like I did not function well during a code", (correlation coefficient was $0,424, \mathrm{p}=0,004)$, "When hospital policies/procedures are conflicting" (correlation coefficient was $0,381, \mathrm{p}=0,011$ ), "When we code a patient and I believe we should not code" (correlation coefficient was $0,507, \mathrm{p}=<$ 0,001), "When I have trouble reading the ECG", (correlation coefficient was 0,435, $\mathrm{p}=0,003)$, "When I code some patients only because hospital policy says I must", (correlation coefficient was $0,472, p=0,001$ ), "When a nurse manager/supervisor criticizes me when I have done my best" (correlation coefficient was $0,318, \mathrm{p}=$ 0,035), and "When a nurse manager does not provide assistance during a code" (correlation coefficient was $0,499, \mathrm{p}=0,001$ ).

The claim "When I lose my confidence during a code" correlated with the following claims: "When I am unable to make a properly functioning piece of equipment operate", (correlation coefficient was $0,441, \mathrm{p}=0,003$ ), "When I have trouble reading the ECG" (correlation coefficient was $0,415, \mathrm{p}=0,005$ ), "When a nurse manager/supervisor criticizes me when I have done my best", (correlation coefficient was $0,374, \mathrm{p}=0,012$ ), and "When a nurse manager does not provide assistance during a code" (correlation coefficient was 0,369, $\mathrm{p}=0,014$ ).

The claim "When a patient's family think I can keep him/her alive" correlated with the claim "When we code a patient and I believe we should not code" (correlation coefficient was $0,440, p=0,003)$.

The claim "When I am unable to make a properly functioning piece of equipment operate" correlated with the following claims: "When hospital policies/procedures are conflicting" (correlation coefficient was 0,340,p =0,024), "When I have trouble reading the ECG" (correlation coefficient was $0,434, \mathrm{p}=0,003$ ), "When a nurse manager/supervisor criticizes me when I have done my best" (correlation coefficient was $0,368, \mathrm{p}=0,014)$, and "When a nurse manager does not provide assistance during a code" (correlation coefficient was $0,344, \mathrm{p}=0,022$ ).

The claim "When we code a patient and I believe we should not code" correlated with the claim "When I code some patients only because hospital policy says I must" (correlation coefficient was $0,492, \mathrm{p}=0,001$ ). 
The claim "When I have trouble reading the ECG" correlated with the claim "When I code some patients only because hospital policy says I must" (correlation coefficient was $0,485, \mathrm{p}=0,001$ ), and "When a nurse manager does not provide assistance during a code" (correlation coefficient was 0,519, $\mathrm{p}=<0,001$ ).

\section{$4 \quad$ Discussion}

In the present research, our goal was to find out how participation in resuscitation processes affects healthcare professionals/registered nurses. Many authors state that participation in resuscitation may have some impact on healthcare professionals. Nurses involved in unsuccessful resuscitation cases can experience certain levels of stress (McMeekin, et al., 2017).

Critical care nurses who experience direct exposure to a traumatic event have the potential for the development of unresolved stress that can result in symptoms of Post-Traumatic Stress Disorders (PTSD). 22 percent of nurses involved in end-oflife issues had symptoms of PTSD, and 18 percent met the diagnostic criteria for a clinical diagnosis of PTSD. It is possible that PTSD symptoms are likely to occur in critical care nurses as a result of the repetitive stress associated with unsuccessful cardiopulmonary resuscitations (e.g. post-code stress) and the use of ineffective coping behaviors (Mealer, et al., 2007). Existing literature confirms that critical care nurses who participate in CPR report feelings of anxiety, grief, regret, anger, futility and helplessness, which may further exacerbate their subsequent levels of postcode stress (McMeekin, et al., 2017; Ganz, et al., 2013; Hinderer, 2012; Kelly, et al., 2008). The literature also documents a variety of coping behaviors to alleviate or often suppress emotions created by stress. Critical and acute care nurses exposed to traumatogenic events exhibit several behavioral coping strategies used to prevent psychological distress and maintain a state of psychological well-being (Desbiens \& Fillion, 2007; Jaracz, 2005). Coping behaviors can be categorized into two broad groups, effective and ineffective behaviors. Effective coping behaviors decrease or eliminate specific stress and significantly decrease traumatic stress, whereas ineffective behaviors such as avoidance and use of medicines, significantly increase psychological stress and decrease psychological health (Happell, et al., 2013; Schreuder, et al., 2012; Buurman, et al., 2011; Von Rueden, et al., 2010). 
In Slovenia, research concerning nurses who work in emergency care was carried out and the results show that 35 percent of nurses believe that they are, as a result of the demands of work, under constant stress. 45 percent of them believe that they are often stressed; 15 percent of them believe that they are occasionally under stress; and, only 5 percent of them believe that stress is very rarely present. A majority of them (75 percent) think that the job is psychologically demanding, and 60 percent of them think that the work is physically exhausting. 60 percent of them occasionally or often notice signs of being overburdened. Nearly 50 percent of nurses think that their work more or less affects their private and family life (Kmetič, 2018).

Jus (2017), in his research among healthcare workers in the Slovenian emergency centers, did not find statistically significant differences in the level of the perception of stress among the paramedics and doctors $(p=0,095)$. However, he did find a statistically significant relationship in the degree of the perceived stress and negative aspects of mood $(p=<0,001)$. Specifically, he observed that 71 percent of the respondents believe that they are working in a stressful environment, and 26 percent of them claim that their work environment is extremely stressful. Only 3 percent of the respondents did not find work in prehospital environment as stressful. Goranski (2011) reports that 59 percent of the emergency nurses who were involved in the research in Slovenia rated their job as 'often stressful'. The same results were obtained by Firdousa (2017), who observed that more than 50 percent of emergency nurses are exposed to high stress because of their work demands.

Spencer et al. (2019) report that nearly 10 percent of acute care staff screened positive for PTSD as a result of attending in-hospital cardiac arrest situations, and an addtional 47 percent of staff declared symptoms of trauma, with junior staff being at highest risk of developing trauma symptoms. Furthermore, very few debriefs take place after resuscitations. One of the reasons for that is the lack of debrief training among cardiac arrest team leaders. More support is required for acute care nursing and medical staff following an in-hospital cardiac arrest. A longitudinal study of 386 London Ambulance Paramedics found an 8,6 percent prevalence of PTSD episodes over two years and a meta-analysis estimated a rate of 11 percent in paramedics (Petrie, et al., 2018, Wild, et al., 2016). 
Spencer also reports an insufficiency of debriefing after resuscitations. Out of 1463 cardiac arrest attendances, only 258 were followed by a debrief (17, 6 percent). There was no statistically significant difference between the chances of a debrief attendance occurring after a fatal resuscitation attempt compared with a non-fatal one. The majority of staff found a debrief to be a positive experience. The most frequently stated reasons were that the debrief session offered a feeling of support $(72,4$ percent), that the session allowed staff/team the opportunity to ask or answer questions ( 69 percent); and, that the debrief session generally allowed the staff to feel better (66,4 percent). In contrast, negative impacts of a debrief session were uncommon. The most frequent reason for finding the debrief a negative experience was the debrief being poorly organized (12,9 percent) (Spencer, et al., 2019).

We used the Post-Code Stress Scale in our research (Cole, Slocumb \& Muldon Mastey, 2001). This Scale was specially made to measure psychological stress associated with CPR perceived by those nurses who are performing the procedure.

Based on the literature reviewed, we decided to combine the last two estimates as burdensome (most disturbing) answers into a single claim (4 and 5). Higher scores reflect higher levels of postcode stress (McMeekin, et al., 2017; Cole, Slocumb \& Muldoon Mastey, 2001).

The claim "When my hands shake during a code" was not so disturbing for the respondents. Shaky hands may be present during a code, but it seems to be the most negligible problem of all twenty claims. Fewer than a quarter (22,8 percent) of the respondents were moderately or very disturbed by this problem. The second claim "When my peers are quick to notice and point out that I made a mistake" was slightly more disturbing for the respondents. 29,5 percent of the respondents answered that this bothered them moderately or a lot. The criticism from the peers also did not present a big burden for the respondents. The third claim "When I feel like I did not function well during a code" was perceived as burdensome for the respondents. More than 68 percent of the respondents decided for the answers 4 and 5. The claim "When more than one doctor gives orders during a code" was even more disturbing, because 77,3 percent of the respondents claimed that it bothers them moderately and a lot (Table 2). This may put nurses under additional stress, as they need to rapidly determine what initial actions to take, especially in terms of what would most beneficial for the patient. This claim supports the fact that it is important to appoint 
a team leader before or during resuscitation. Half of the respondents, however, were partly or very bothered by the fact that they began to doubt themselves during the code (Table 2). Spencer, et al., (2019) reported that 26 percent of the respondents in their survey stated they experienced significant loss in their confidence in their professional abilities following the in-hospital cardiac arrest.

On the one hand, the respondents in our study were moderately burdened by expectations of the patients' relatives (38,6 percent of the respondents chose the last two claims). But they were disturbed a lot when they had problems operating the equipment $(72,8$ percent of the respondents chose the answer "it bothers me moderately and a lot") (Table 2). Depending on the organization of work, nurses are usually responsible for checking and making sure the resuscitation equipment is operational. Malfunctioning or nonfunctioning of the equipment during resuscitation can result in resuscitation failure, for which the nurses will be held responsible. The respondents were upset by the fact that their actions sometimes conflicted with hospital policies (70,5 percent opted for the last two claims). In Slovenia, nurses are rather restricted in their competencies. Obviously, this puts a considerable burden on them and creates conflict between their competencies on the one hand and hospital policies and procedures on the other, when the two do not completely work in harmony. Slightly over a half of the respondents $(52,3$ percent) did not like the fact that they had to resuscitate patients who, in their opinion, should not be resuscitated. And less than half of them (45 percent) were bothered moderately or a lot, if they could not read the ECG properly. The last statement refers to the situation when the nurse fails to reliably identify the condition from the ECG record, which can be very important in emergencies; timely identification of the situation, timely activation of additional assistance, and implementation of emergency measures. An appropriate response in emergencies, however, is also required by nurses. However, the mentioned situation is also a consequence of the fact that in principle, nurses in Slovenia do not have a defined reading of the ECG record in their competencies. As a result, they also have less knowledge and experience in this field (Table 2).

Slightly more than half of the respondents ( 56,8 percent) stated that it bothers them if they have to resuscitate patients strictly based on hospital policy. 72,7 percent of the respondents did not like the critiques from their superiors which were, in their opinion, not justified. Even though the interviewees were not bothered a lot by the 
criticism from their colleagues, the criticism received from their superiors was the third most disturbing claim. The next claim can also be related to superiors failing to provide assistance in specific situations. 63,7 percent of the respondents were moderately or very disturbed by the fact that they did not receive help during a code. 47,8 percent of the respondents had a problem with the possibility that they made a mistake. 61,3 percent of the respondents reported that they have problems if they do not have some time after resuscitation to take care of themselves (Table 2). Spencer et al. (2019) reported that taking a break after resuscitation seems to correlate with better mental and physical health. Spencer found, for example, that staff who never took a break after resuscitation, had 2,4 times higher odds of developing PTSD than the staff who did rest after resuscitation. 54,5 percent of the respondents were disturbed moderately and a lot when answering that "people think that they can function well immediately after a code" (Table 2). 60 respondents out of 312 (19,2 percent) of the staff who participated in Spencer's survey reported resentment in having to return to work immediately after an in-hospital cardiac arrest (Spencer, et al., 2019). 61,3 percent of the respondents were bothered moderately or a lot when they resuscitated a young person. Slightly more than 40 percent were bothered by the fact that no one talked about resuscitation after it was finished. More than half of the respondents $(61,4$ percent) were bothered if they had second thoughts about the possibility that they may have missed a sign that might predict the code. Signs of a sudden deterioration, when properly and quickly observed, can save lives, and since nurses spend most of the time with patients, it is their professional responsibility to notice these changes in a timely manner. Less than a third of the respondents $(29,5$ percent) were disturbed moderately or a lot by unsuccessful reanimation (Table 2).

Based on our findings we conclude that the respondents had the least difficulty with the situations of "shaky hands during a code", "criticism of colleagues" and even when the resuscitation was not successful. The mean value respecting these three situations was lower than 3 (Table 3). We were surprised by the last finding, which is contrary to the findings in literature (McMeekin, 2017, Fitzpatrick, 2010, Mealer, 2007). The claims that were most disturbing for the respondents (the mean value was above 4 or just under 4 ) were as follows:

(a) the biggest surprise was the claim with the highest score "When I am unable to make a properly functioning piece of equipment operate during a code." (Table 3). 
However, the fact is that inoperative resuscitation equipment (e.g. AED, etc.) can lead to failed resuscitations. Nurses have the responsibility to regularly check the functioning of resuscitation equipment. Therefore, regular control, in accordance with the applicable procedures in the department, is necessary and as such must not be ignored. It is unacceptable that a failure of certain equipment is detected only at the time of an actual resuscitation case. Data-driven debriefs focused on performance aspects of resuscitation procedure, and when associated with reduced time before the first compression is given, as well as shorter hands-off compression periods, can result in better patient condition outcomes (Resuscitation Council UK, Resuscitation guidelines, 2015, Couper, et al., 2015, Bahjani, et al., 2010).

(b) Secondly, the claim "When hospital policies/procedures are conflicting" may also be reasonable. The situation when a person is limited by competencies and measures that are urgently needed is very burdensome. Often nurses know what needs to be done in a given situation (e.g., the application of a particular therapy). But they do not have the competence to make an independent decision. Abandonment of the measure, however, can also be fatal. Due to Slovenian law, nurses have limited competencies during resuscitation too. Certain procedures are not clearly defined whether the nurse can do them during resuscitation if a doctor is not present. And we also know some life-threatening situations in which the nurses alone, can't perform procedures that can save a life. Limited competencies in the absence of a doctor can even decide whether or not the person in need will survive until additional help arrives (eg., the use or not use of adrenaline in the event of an anaphylactic reaction).

The aforementioned statement refers to events when a nurse has to perform or abandon specific tasks. However, the nurse, by itself would have decided otherwise. The current practice in Slovenia leaves the decision-making to doctors. Current guidelines emphasize team decision-making (e.g., when to stop resuscitation, etc.). Thus, team members are involved in decisions that result in further procedures or. abandonment of them. With this way of working, nurses would have a greater sense of belonging to teamwork. They would also find it easier to accept decisions, as they would also have an impact on them. Mentioned the way of communicating would probably mentally relieve the doctors and the team members would help him make decisions in the most challenging situations. 
(c) Thirdly, the claims with the same value were "When more than one doctor gives orders during a code" and "When a nurse manager/supervisor criticizes me when I have done my best". The latter statement is interesting because the colleagues' criticism was not considered disturbing, while the criticism of the leader ranked highly among the answers. The same can be considered about the claim regarding receiving more orders from different doctors. This kind of work can confuse the rest of the resuscitation team. It is essential that it is well-understood who the team leader is, and the leader should be one person (the most experienced one, the most available one, etc.). This person should delegate tasks to the rest of the team and team members should give them feedback.

\section{$5 \quad$ Conclusions}

In the study, we have found that participation in resuscitation can cause certain stressful moments to the nurses. But the stress is not very high in the majority cases. Minor problems were observed in a purely physical reaction to stress, such as shaky hands. The responding nurses also did not have major problems with criticism from their colleagues. Furthermore, even unsuccessful resuscitations did not overly burden the respondents. Perhaps this finding can best be explained by the fact that when a person is certain that he has performed his task to the best of his capabilities he can accept the outcome, even when the outcome is not optimal, or may have resulted in an inanimation. The simple fact is that nurses and other medical staff cannot control all aspects of their work. Certain elements are beyond their control, and our findings support the conclusions that nurses understand this and can live with it. On the other hand, critiques from the supervisors or superiors were one of the claims that have proven to be one of the most burdensome. The respondents stated that one of the highest stress-causing situations is when they are unable to make a properly functioning piece of equipment operate during a code. Respondents also reported being highly disturbed in situations both where they received more orders from more doctors and where they feel that their beliefs are in contradiction with hospital policies. We believe that some systemic solutions should be implemented. We need to identify staff at risk (burnt out staff, those exposed to severe stress, etc.) and take steps to provide psychological support to those healthcare workers. Last but not least, effective debriefing is also necessary. 


\section{References}

Balažic, J. (2006) Pravni in etični vidiki prve pomoči, In: Ahčan, U. (eds.) Prva pomoč (Ljubljana: Rdeči križ Slovenije), pp. 3-4.

Ballew, K. (1997) Cardiopulmonary resuscitation, Recent advances, British Medical Journal, 314(7092), pp. 1462-1466.

Bhanji, F., Mancini, M. E., Sinz, E., et al. (2010) 2010 American Heart Association Guidelines for Cardiopulmonary Resuscitation and Emergency Cardiovascular Care, Circulation, 122(18_S3), pp. S920-S933, doi: 10.1161/CIRCULATIONAHA.110.971135.

Buurman, B. M., Mank, A. P. M., Beijer, H. J. M., \& Olff, M. (2011) Coping with serious events at work: a study of traumatic stress among nurses, Journal of the American Psychiatric Nurses Association, 17(5), pp. 321-329, doi: 10.1177/1078390311418651.

Chang, S. H. et al. (2009) Who survives cardiac arrest in the intensive care units?, Journal of Critical Care, 24(3), pp. 408-414, doi: 10.1016/j.jcrc.2008.10.006.

Cole, F., Slocumb, E. M. \& Muldoon Mastey, J. (2001) A measure of critical care nurses' post-code stress, Journal of Advanced Nursing, 34(3), pp. 281-288, doi: 10.1046/j.1365-2648.2001.01756.x.

Couper, K., Kimani, P., Abell, B., et al. (2015) The System-Wide Effect of Real-Time Audiovisual Feedback and Post-event Debriefing for In-Hospital Cardiac Arrest: The Cardiopulmonary Resuscitation Quality Improvement Initiative, Critical Care Medicine, 43(11), pp. 2321-2331, doi: 10.1097/CCM.0000000000001202.

Desbiens, J. \& Fillion, L. (2007) Coping strategies, emotional outcomes and spiritual quality of life in palliative care nurses, International Journal of Palliative Nursing, 13(6), pp. 291-300, doi: 10.12968/ijpn.2007.13.6.23746.

Dwyer, T. \& Williams, M. L. (2002) Nurses' behaviour regarding CPR and the theories of reasoned action and planned behaviour, Resuscitation, 52(1), pp. 85-90, doi: 10.1016/s03009572(01)00445-2.

Enohumah, K. O. et al. (2006) Outcome of cardiopulmonary resuscitation in intensive care units in a university hospital, Resuscitation, 71(2), pp. 161-170, doi: 10.1016/j.resuscitation.2006.03.013.

Fitzpatrick, J. J., Campo, T. M., Graham, G. \& Lavandero, R. (2010) Certification, empowerment, and intent to leave current position and the profession among critical care nurses, American Journal of Critical Care, 19(3), pp. 218-226, doi: 10.4037/ajcc2010442.

Firdousa, J. (2017) Level of Stress Among Staff Nurses Working in Emergency and General Wards of Skims Hospital, International Journal of Advanced Research, 5(4), pp. 1469 - 1476, doi: 10.21474/IJAR01/3969.

Ganz, F. D., Kaufman, N., Israel, S. \& Einav, S. (2013) Resuscitation in general medical wards: who decides?, Journal of Clinical Nursing, 22(5/6), pp. 848-855, doi: 10.1111/j.13652702.2012.04240.x.

Gershengorn, H., Li, G., Kramer, A. \& Wunsch, H. (2012) Survival and functional outcomes after cardiopulmonary resuscitation in the intensive care unit, Journal of Critical Care, 27(4), p. 421.e917, doi: 10.1016/j.jcrc.2011.11.001.

Goranski, S. (2011) Stres pri delu medicinskih sester v UKC Maribor; magistrsko delo. (Maribor: Univerza v Mariboru, Ekonomsko - poslovna fakulteta).

Happell, B., Reid-Searl, K., Dwyer, T., Caperchione, C. M., Gaskin, C. J., \& Burke, K. J. (2013) How nurses cope with occupational stress outside their workplaces, Collegian, 20(3), pp. 195-199, doi: 10.1016/j.colegn.2012.08.003.

Hinderer, K. A. (2012) Reactions to patient death: the lived experience of critical care nurses, Dimensions of Critical Care Nursing, 31(4), pp. 252-259, doi: 10.1097/DCC.0b013e318256e0f1.

Hinkle, D. E., Wiersma, W. \& Jurs, S. G. (2003) Applied Statistics for the Behavioral Sciences, 5 th ed. (Boston: Houghton Mifflin).

Inwood, H. (1996) Knowledge of resuscitation, Intensive Crit Care Nursing, 12(1), pp. 33-39, doi: 10.1016/s0964-3397(96)81653-3.

Issak, C. \& Paterson, B. (1996) Critical care nurses' lived experience of unsuccessful resuscitation, Western Journal of Nursing Research, 18(6), pp. 688-702, doi: 10.1177/019394599601800606. 
Jaracz, K., Gorna, K., \& Konieczna, J. (2005) Burnout, stress and styles of coping among hospital nurses, Roczniki Akademii Medycznej v Bialymstoku, 50(S1), pp. 216-219.

Jus, A. (2017) Custveno delo kot pov zroúitelj stresa pri delu zdravstvenega osebja v prehospitalnem okolju; magistrsko delo (Maribor: Univerza v Mariboru, Fakulteta za zdravstvene vede).

Kelly, J. (2008) Nurses' and doctors' perspectives on slow codes, Nursing Ethics, 15(1), pp. 110-120, doi: $10.1177 / 0969733007084164$.

Kešpet, B. (2013) Pravna in etična vprašanja v nujni medicinski pomoči (Celje: Visoka zdravstvena šola Celje). Kmetič, P. (2018) Stres in obremenjenost osebja zdravstvene nege v urgentni dejavnosti; diplomsko delo (Maribor: Univerza v Mariboru, Fakulteta za zdravstvene vede).

Korošec, D. (2004) Medicinsko kazensko pravo (Ljubljana: Cankarjeva založba).

Kraljić, S. (2010) Nekateri vidiki pacientove avtonomije, In: Rijavec, V. \& Flis, V. (eds.) Medicina in pravo - sodobne dileme II (Maribor: Pravna fakulteta Univerze v Mariboru), pp. 187-199.

Laws, T. (2001) Examining critical care nurses' critical incident stress after in-hospital cardiopulmonary resuscitation (CPR), Australian Critical Care, 14(2). pp. 76-81, doi: 10.1016/s10367314(01)80010-2.

McGowan, J., Graham, C. \& Gordon, M. (1999) Appointment of a resuscitation training officer is associated with improved survival from in-hospital ventricular fibrillation/ventricular tachycardia cardiac arrest, Resuscitation. 41, pp. 169-173, doi: 10.1016/s0300-9572(99)00046-5.

McMeekin, D. E., Hickman, R. L., Douglas, S. L. \& Kelly, C. G. (2017) Stress and coping of critical care nurses after unsuccessful cardiopulmonary resuscitation, American Journal of Critical Care, 26(2), pp. 128-135, doi: 10.4037/ajcc2017916.

Mealer, M. L. et al. (2007) Increased prevalence of post-traumatic stress disorder symptoms in critical care nurses, American Journal of Respiratory and Critical Care Medicine, 175(7), pp. 693-697, doi: 10.1164/rccm.200606-735OC.

Mukaka, M. M. (2012) Statistics corner: a guide to appropriate use of correlation coefficient in medical research, Malawi Medical Journal, 24(3), pp. 69-71.

Myrianthefs, P. et al. (2003) Efficacy of CPR in a general adult ICU, Resuscitation, 57(1), pp. 43-48, doi: 10.1016/s0300-9572(02)00432-x.

Panesar, S. S., Ignatowicz, A. M., \& Donaldson, L. J. (2014) Errors in the management of cardiac arrests: An observational study of patient safety incidents in England, Resuscitation, 85(12), pp. 1759-1763, doi: 10.1016/j.resuscitation.2014.09.027.

Pembeci, K. et al. (2006) Assessment of the success of cardiopulmonary resuscitation attempts performed in a Turkish university hospital, Resuscitation, 68(2), pp. 221-229, doi: 10.1016/j.resuscitation.2005.07.003.

Ryan, C. (1998) Matters of life and death: the challenge of CPR decision making. How can we improve patient involvement in this complex process? Medical Journal of Australia, 169(3), pp. 124-125.

Petrie, K.., Milligan-Saville, J., Gayed, A. et al. (2018) Prevalence of PTSD and common mental disorders amongst ambulance personnel: a systematic review and meta-analysis, Social Psychiatry and Psychiatric Epidemiology, 53(9), pp. 897-909, doi: 10.1007/s00127-018-1539-5.

Raosoft (2004) Sample size calculator, retrieved from: http://www.raosoft.com/samplesize.html (10. 1. 2020).

Resuscitation Council UK (2015), Resuscitation guidelines, retrieved from: https://www.resus.org.uk/resuscitation-guidelines/ (10 January 2020).

Schreuder, J. A. H. et al. (2012) Coping styles relate to health and work environment of Norwegian and Dutch hospital nurses: a comparative study, Nursing Outlook, 60(1), pp. 37-43, doi: 10.1016/j.outlook.2011.05.005.

Spencer, S. A., Nolan, J. P., Osborn, M., \& Georgiou, A. (2019) The presence of psychological trauma symptoms in resuscitation providers and an exploration of debriefing practices, Resuscitation, 142, pp. 175-181, doi: 10.1016/j.resuscitation.2019.06.280.

Von Rueden, K. T., Hinderer, K. A., McQuillan, K. A., et al. (2010) Secondary traumatic stress in trauma nurses: prevalence and exposure, coping, and personal/environmental characteristics, Journal of Trauma Nursing, 17(4), pp. 191-200, doi: 10.1097/JTN.0b013e3181ff2607. 
Wild, J., Smith, K. V., Thompson, E., et al. (2016) A prospective study of pre-trauma risk factors for post-traumatic stress disorder and depression, Psychological Medicine, 46(12), pp. 2571-2582, doi: 10.1017/S0033291716000532.

Zuzelo, P. R. (2007) Exploring the moral distress of registered nurses, Nurse Ethics, 14(3), pp. 344-359, doi: $10.1177 / 0969733007075870$.

\section{Legal sources:}

Kazenski zakonik (KZ-1). Uradni list RS, št. 50/12-UPB, 6/16, 54/15, 38/16, 27/17, 23/20, 91/20.

Kodeks etike v zdravstveni negi in oskrbi Slovenije (2014). Uradni list RS, št. 71/14. Retrieved from: https://www.uradni-list.si/_pdf/2014/Ur/u2014071.pdf (20 January 2020).

Kodeks medicinske deontologije Slovenije (1997). Zdravniška zbornica Slovenije. Retrieved from: http://www.kme-nmec.si/files/2018/03/kodeks-medicinske-deontologije-Slovenije.pdf

(8 June 2019).

Kodeks zdravniške etike. (2016). Slovensko zdravniško društvo in Zdravniška zbornica Slovenije. Retrieved from: https://www.zdravniskazbornica.si/docs/default-source/zbornicniakti/kodeks-2016.pdf?sfvrsn=2 (24 August 2020).

NIJZ, Nacionalni inštitut za javno zdravje. Podatkovni portal. Zaposleni po poklicnih skupinah in statističnih regijah. Retrieved from: https://podatki.nijz.si/Table.aspx?layout=tableViewLayout2\&px_tableid=BPI_TB01.px\&px _path $=$ NIJZ $\% 20$ podatkovni $\% 20$ portal__5\%20Viri $\% 20 \mathrm{v} \% 20$ zdravstvu__ $\% 20$ Izvajalci $\% 20 \mathrm{z}$ dravstvene $\% 20$ dejavnosti\&px_language $=$ sl\&px_db=NIJZ\%20podatkovni $\% 20$ portal\&rxid $=e$ e75d6a7-a295-4f98-8111-0e203b245f33 (last update (16 December 2019).

Zakon o pacientovih pravicah (ZPacP). Uradni list RS, št. 15/08, 55/17.

Zakon o zdravniški službi (ZZDrS). Uradni list RS, št. 72/06 - UPB, 15/08 - ZPacP, 58/08, 107/10 - ZPPKZ, 40/12 - ZUJF, 88/16 - ZdZPZD, 40/17, 64/17 - ZZDej-K, 49/18, 66/19.

Zakon o zdravstveni dejavnosti (ZZDej). Uradni list RS, št. 23/05 - uradno prečiščeno besedilo, 15/08 - ZPacP, 23/08, 58/08 - ZZdrS-E, 77/08 - ZDZdr, 40/12 - ZUJF, 14/13, 88/16 ZdZPZD, 64/17, 1/19 - odl. US, 73/19, 82/20. 